\title{
Effects of massive transfusion on oxygen availability
}

\author{
Heart Institute, Hospital das Clínicas, Faculdade de Medicina, Universidade de São Paulo - São Paulo, Brazil
}

\begin{abstract}
Objectives: To determine oxygen derived parameters, hemodynamic and biochemical laboratory data (2,3 Diphosphoglycerate, lactate and blood gases analysis) in patients after cardiac surgery who received massive blood replacement. Design: Prospective study. Setting: Heart Institute (Instituto do Coração), Hospital das Clínicas, Faculdade de Medicina, Universidade de São Paulo, Brazil. Participants: Twelve patients after cardiac surgery who received massive transfusion replacement; six of them evolved to a fatal outcome within the three-day postoperative follow-up. Measurements and Main Results: The non-survivors group $(n=6)$ presented high lactate levels and low $P_{50}$ levels, when compared to the survivors group $(p<0.05)$. Both groups presented an increase in oxygen consumption and $\mathrm{O}_{2}$ extraction, and there were no significant differences between them regarding these parameters. The 2,3 DPG levels were slightly reduced in both groups. Conclusions: This study shows that patients who are massively transfused following cardiovascular surgery present cell oxygenation disturbances probably as a result of $\mathrm{O}_{2}$ transport inadequacy.
\end{abstract}

UNITERMS: Cardiac Surgery. Massive Transfusion. Oxygen Consumption.

\section{INTRODUCTION}

$\mathrm{N}$ ormal cellular function depends on a supply of oxygen adequate to meet metabolic needs. The supply of oxygen, in turn, depends on cardiac output, hemoglobin concentration and function, and the partial pressure of oxygen in arterial blood.

Circulatory oxygen supply may be evaluated by several variables. The oxygen extraction ratio $\left(\mathrm{O}_{2}\right.$ ER $)$

\author{
Address for correspondence: \\ José Otávio Costa Auler Jr. \\ Hospital das Clínicas. Prédio dos Ambulatórios \\ Divisão de Anestesia/Disc. de Anestesiologia \\ Av. Dr. Enéas de Carvalho Aguiar $s / n$ \\ São Paulo/SP - Brasil - CEP 05403-011
}

represents the amount of oxygen removed by the tissues. Oxygen delivery $\left(\mathrm{DO}_{2}\right)$ to the tissues is calculated as the product of cardiac output and arterial $\mathrm{O}_{2}$ content expressed in $\mathrm{ml} /$ minute. $\mathrm{VO}_{2}$ is a measure of the $\mathrm{O}_{2}$ extracted by the cells and is calculated as the product of cardiac output and arteriovenous $\mathrm{O}_{2}$ difference $\left[\mathrm{C}(\mathrm{a}-\mathrm{v}) \mathrm{O}_{2]}\right]$. These three variables are used to assess the bulk movement of $\mathrm{O}_{2}$ by circulation $^{(1)}$. However, there are few practical methods to determine if oxygen supply is adequate at any given point in time to meet the oxygen demands of critical patients. Therefore, oxygen supply/demand imbalances may result in tissue oxygen deficits, that can be manifested by organ dysfunction. Oxyhemoglobin dissociation is closely related to oxygen delivery. Hydrogen ion concentration, carbon dioxide tension, temperature, and erythrocyte 2,3-diphosphoglycerate concentration $(2,3$ DPG) are the main factors affecting $\mathrm{O}_{2}$ affinity ${ }^{(2,3,4,5)}$. 
During low flow states, increased blood lactate levels can be directly related to a reduction in systemic oxygen supply. In severely hemorrhagic patients, the many variables involved during treatment make it difficult to obtain an index for prognosis and therapeutic adequacy. This explains the scarcity of studies on oxygen transport in hemorrhagic patients.

The main purpose of this study is to verify any correlation between oxygen derived parameters, hemodynamic data and biochemical data in patients submitted to a massive transfusion during hemorrhagic shock after surgery.

\section{METHODS}

\section{Patient Population}

The study was approved by the Ethical Committee of the Heart Institute and written informed consent was obtained from all patients. Twelve adult patients, who underwent elective cardiovascular surgery, were consecutively studied in the postoperative period, independently of previous diagnosis. The criteria employed were: bleeding at least one volemia $\left(60 \mathrm{ml} . \mathrm{kg}^{-1}\right)$ in the first 24 hours and survival until the third postoperative day. Six patients were submitted to valve replacement, two to coronary bypass graft and four to correction of thoracic aortic aneurysm. Patients were studied after legal guardian consent was obtained. All patients were submitted to a standard procedure for bypass (non pulsatile flow and bubble oxygenator, hypothermia down to $32^{\circ} \mathrm{C}$ ) and anesthesia (fentanyl, pancuronium bromide and midazolam).

\section{Hemodynamic and Biochemical Measurements}

All patients were monitored using electrocardiography, intra-arterial cannulae and $7 \mathrm{Fr}$. thermistor tipped pulmonary artery catheters. Hemodynamic measurements included: systolic, diastolic, and mean arterial pressures; pulmonary artery pressure, right atrial pressure (RAP) and pulmonary wedge arterial pressure (PWAP). Cardiac output was measured in triplicate by the thermodilution method. Arterial and pulmonary artery blood samples were drawn for hemoglobin concentrations and blood gas analysis. $\mathrm{PaO}_{2}$, $\mathrm{PvO}_{2}$ and $\mathrm{pH}$ measurements were made with a Radiometer ABL 300 (Copenhagen, Denmark) and $\mathrm{O}_{2}$ saturation was measured by an optical oximeter (Radiometer OS M2-Hemoximeter). $\mathrm{PvO}_{2}$ was determined in the blood collected from the distal part of Swan-Ganz catheters.
The $\mathrm{P}_{50}$ values were estimated from the measured $\mathrm{PvO}_{2}$ and $\mathrm{O}_{2}$ saturation of mixed venous blood samples using the Severinghaus formula:

Estimated $\mathrm{P}_{50}=26.6 \times \mathrm{PvO}_{2} / \mathrm{PvO}_{2}$ Sat, in which $\mathrm{PvO}_{2}$ Sat is the $\mathrm{PO}_{2}$ on the standard oxygen-hemoglobin dissociation curve (OH-DC) corresponding to the measured $\mathrm{O}_{2}$ saturation (Standard $\mathrm{P}_{50}=27$ torr at $\mathrm{pH} 7.4$, temperature $37^{\circ} \mathrm{C}$ and $\mathrm{PaCO}_{2}$ of 40 torr $)^{(6,7)}$. Arteriovenous oxygen difference $\left.(\operatorname{avDO})_{2}\right)$, oxygen availability $\left(\mathrm{DO}_{2}\right)$, oxygen extraction ratio $\left(\mathrm{O}_{2} \mathrm{ER}\right)$, and oxygen consumption $\left(\mathrm{VO}_{2}\right)$ were determined by standard equations. Erythrocyte 2,3 diphosphoglicerate was determined immediately from trichloroacetic extracts of heparinized venous blood through a spectrophotometric assay (Sigma Chemical Co. Ltd, St. Louis, USA). Plasma lactate was analyzed by the automated enzymatic procedure (U.V. enzymatic test Merck Inc., Chemical Industries, Brazil).

All measurements were carried out on the first, second and third postoperative days, six times daily, every four hours. The results were presented as a mean of these values. The blood temperature was measured by a SwanGanz catheter thermistor. The core temperature was maintained between $36.5^{\circ}$ and $37.5^{\circ}$ Celsius, using a thermal blanket. Inotropes (dopamine, dobutamine, norepinephrine) and vasodilators (nitroprusside, nitroglycerin) were given in an attempt to obtain a cardiac index greater than 3.0 L. $\mathrm{min}^{-1} \cdot \mathrm{m}^{-2}$. Atrial filling pressure was maintained at the utmost physiological value to obtain an optimal cardiac output. All patients were submitted to mechanical ventilation until the hemorrhage was controlled. Blood transfusion was given to control hemorrhage and maintain hemoglobin above $10 \mathrm{~g} \cdot \mathrm{dl}^{-1}$. The blood used was stored for no longer than 24 hours after collection.

\section{Statistical analysis}

The data was processed through variance analysis for repeated measurements, with $p<0.05$ being considered significant.

\section{RESULTS}

The amount (mean values) of blood component replacement during surgery, immediately after, and in the first postoperative day was $127.4 \mathrm{~mL} \cdot \mathrm{kg}^{-1}, 81.5 \mathrm{~mL} \cdot \mathrm{kg}^{-1}$ and $44.6 \mathrm{~mL} . \mathrm{kg}^{-1}$ respectively (Fig.1). Replacement consisted of: whole blood, packed red cells, fresh frozen 
plasma, platelets and cryoprecipitate, given as necessary. All patients were submitted to surgical revision of hemostasis in the immediate postoperative period.

By retrospective analysis of patients' outcome, two groups could be defined: survivors $(\mathrm{n}=6)$ and non-survivors $(n=6)$. The mean age of the survivors group was 49.83 \pm 16.81 years and for the non-survivors group $50.67 \pm 15.86$ years. Non-surviving patients died between the third and twentieth postoperative days. The causes of death were: multiple organ failure (4 patients), hemorrhagic brain infarction (1 patient) and generalized sepsis from endocarditis (1 patient).

Biochemical and hemodynamic profiles showed that lactate level was the only discriminatory value between the two groups. The correlation between lactate level and outcome of those patients is shown in figure 2. There was no significant statistical difference regarding blood replacement (fig.1), nor for vasoactive drugs between the groups. Although we did not find a statistical significant difference regarding $\mathrm{PvO}_{2}$, between the groups, this value showed a tendency to decrease in non-surviving patients (Fig. 3).

The 2,3 DPG levels were slightly reduced in both groups on the first postoperative day, and remained at low levels during all determinations. The mean temperature in the non-survival group was consecutively $37.1,36.8,36.9$ ${ }^{\circ} \mathrm{C}$, in the first, second and third postoperative days, and $36.8,37.1,36.8^{\circ} \mathrm{C}$ for the survival group.

The estimated $\mathrm{P}_{50}$ on the first postoperative day was low $(24.82 \pm 2.87$ torr $)$ in the surviving, and very low $(19.08 \pm 2.79$ torr $)$ in the non-surviving patients with a

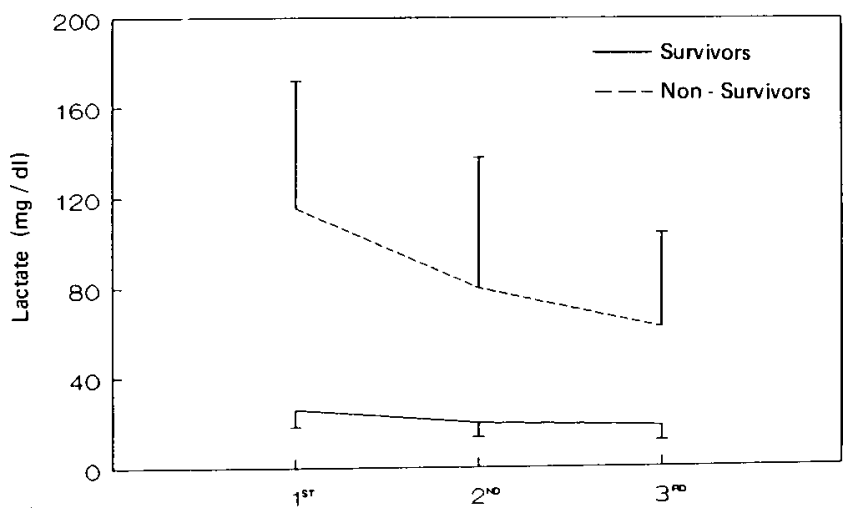

Figure 1 - Lactate levels as function of time. There was a statistical difference between the groups $(p<.05) .1^{\text {st }} \mathrm{PO}$ : first postoperative day, $2^{\text {nd }} \mathrm{PO}$ : second postoperative day, $3^{\text {rd }} \mathrm{PO}$ : third postoperative day. significant difference $(\mathrm{p}<0.05)$. There were no differences between the groups in relation to the analysis of oxygen derived parameters, temperature and hemodynamic data. Although we could not observe a significant variation of this data concerning the postoperative period, the $\mathrm{O}_{2} \mathrm{ER}$ was higher than normal (table1).

\section{DISCUSSION}

The relationship between $\mathrm{VO}_{2}$ and $\mathrm{DO}_{2}$ is of paramount importance in many clinical situations. Whole body total oxygen consumption remains virtually constant at normal or high delivery rates, but becomes limited when oxygen transport decreases to a critical delivery point ${ }^{(8)}$. Therefore, if oxygen availability is compromised, the $\mathrm{O}_{2}$ supply/demand balance can be disrupted and lactic acidosis may occur. At the same time, $\mathrm{O}_{2} \mathrm{ER}$ increases gradually as delivery is reduced, to maintain the $\mathrm{VO}_{2}$, until the critical extraction ratio is reached. In hemorrhagic states, oxygen delivery is critically affected and oxygen transport depends on volemic replacement, hematocrit levels, hemoglobin saturation and cardiac output. Clinically, the hemoglobin oxygen affinity can be estimated by $\mathrm{P}_{50}$ calculation, which represents $50 \%$ of hemoglobin saturation $\left(\mathrm{P}_{50}\right.$ normal value $=26.6 \mathrm{mmHg}$ ).

The rightward shift of $\mathrm{OH}-\mathrm{DC}$ with $\mathrm{P}_{50}$ increase occurs in states of acidemy. This phenomenon is known as the Bohr effect, and is expressed by an OH-DC related

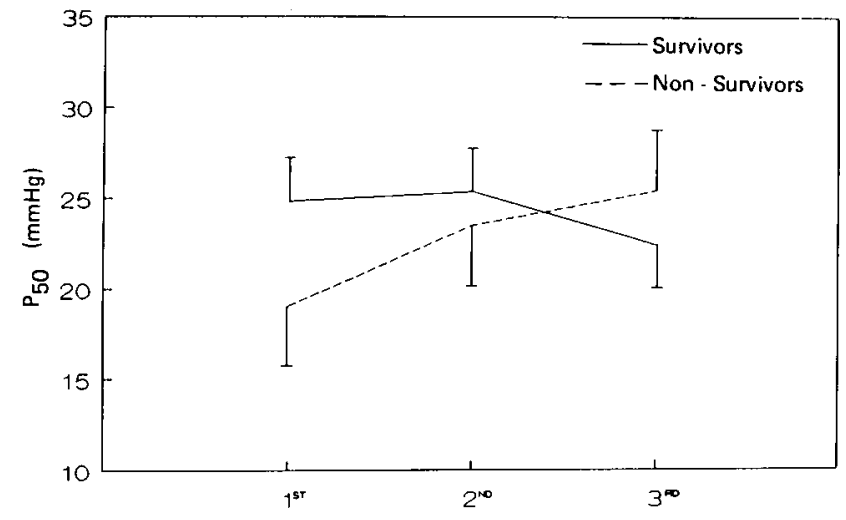

Figure 2 - $\mathrm{P}_{50}$ determination as a function of time. There was no statistical difference between groups except on the $1^{\text {st }}$ postoperative day $(p<.05) .1^{\text {st }} P O$ : first postoperative day, $2^{\text {nd }} P O$ : second postoperative day, $3^{\text {rd }} \mathrm{PO}$ : third postoperative day. 
Table 1

Oxygen Derived Parameters, 2,3 DPG and Hemoglobin Values

\begin{tabular}{lccccc}
\hline VARIABLE & & 1st P.O. & 2nd P.O. & 3rd P.O. & p value \\
\hline DO2 $\mathrm{mL} / \mathrm{min}$ & $\mathrm{S}$ & $1013.30 \pm 260.40$ & $1072.20 \pm 27.10$ & $952.20 \pm 343.80$ & NS \\
& $\mathrm{N}$ & $916.20 \pm 342.30$ & $890.00 \pm 175.00$ & $869.00 \pm 40.30$ & \\
\hline VO2 $\mathrm{mL} / \mathrm{min}$ & $\mathrm{S}$ & $289.30 \pm 73.80$ & $280.30 \pm 123.10$ & $282.80 \pm 58.50$ & $\mathrm{NS}$ \\
& $\mathrm{N}$ & $357.70 \pm 87.90$ & $295.20 \pm 76.50$ & $250.30 \pm 37.10$ & \\
\hline O2ER & $\mathrm{S}$ & $0.31 \pm 0.14$ & $0.27 \pm 0.09$ & $0.32 \pm 0.08$ & \\
& $\mathrm{~N}$ & $0.43 \pm 0.16$ & $0.34 \pm 0.07$ & $0.30 \pm 0.08$ & $\mathrm{NS}$ \\
\hline $\mathrm{PaO} 2$ torr & $\mathrm{S}$ & $90.67 \pm 35.75$ & $75.42 \pm 24.54$ & $63.17 \pm 14.23$ & \\
& $\mathrm{~N}$ & $104.08 \pm 44.35$ & $85.43 \pm 30.93$ & $96.30 \pm 37.10$ & $\mathrm{NS}$ \\
\hline SvO2 \% & $\mathrm{S}$ & $67.62 \pm 13.71$ & $68.08 \pm 9.64$ & $63.32 \pm 8.88$ & \\
& $\mathrm{~N}$ & $55.13 \pm 14.66$ & $62.67 \pm 5.10$ & $68.42 \pm 6.71$ & $\mathrm{NS}$ \\
\hline $\mathrm{Hb} \mathrm{g} / \mathrm{dL}$ & $\mathrm{S}$ & $11.32 \pm 2.18$ & $11.47 \pm 1.42$ & $11.18 \pm 1.47$ & $\mathrm{NS}$ \\
& $\mathrm{N}$ & $11.06 \pm 1.18$ & $11.30 \pm 1.94$ & $10.91 \pm 1.41$ & \\
\hline $2,3 \mathrm{DPG} \mathrm{mol} / \mathrm{mL}$ & $\mathrm{S}$ & $1.42 \pm 0.57$ & $1.37 \pm 0.34$ & $1.40 \pm 0.4$ & $\mathrm{NS}$ \\
& $\mathrm{N}$ & $1.03 \pm 0.23$ & $1.35 \pm 0.27$ & $1.58 \pm 0.33$ & \\
\hline
\end{tabular}

DO2: oxygen delivery; VO2: oxygen consumption; O2ER: oxygen extraction rate; PaO2: arterial oxygen partial pressure; SvO2\%: venous oxygen saturation; Hb: hemoglobin; 2,3 DPG: 2,3 diphosphoglycerate; S: survivors; N: nonsurvivors; NS: statistically not significant (level $p<0.05$ ).

to $\mathrm{pH}$ variation. Clinically, the Bohr effect with its rightward shift in $\mathrm{OH}-\mathrm{DC}$ helps in increasing $\mathrm{O}_{2}$ demand in different situations in which greater $\mathrm{O}_{2}$ availability is needed. Temperature plays an important role in $\mathrm{OH}-\mathrm{DC}$ shifts. A $1^{\circ} \mathrm{C}$ increase in core temperature results in a $\mathrm{P}_{50}$ increase of $1.5 \mathrm{mmHg}$ which allows a bigger $\mathrm{O}_{2}$ supply to tissues. A decrease of only $0.1 \mathrm{pH}$ units means a $3 \mathrm{mmHg}$ increase in $\mathrm{P}_{50} .2,3 \mathrm{DPG}$ is the most common inorganic

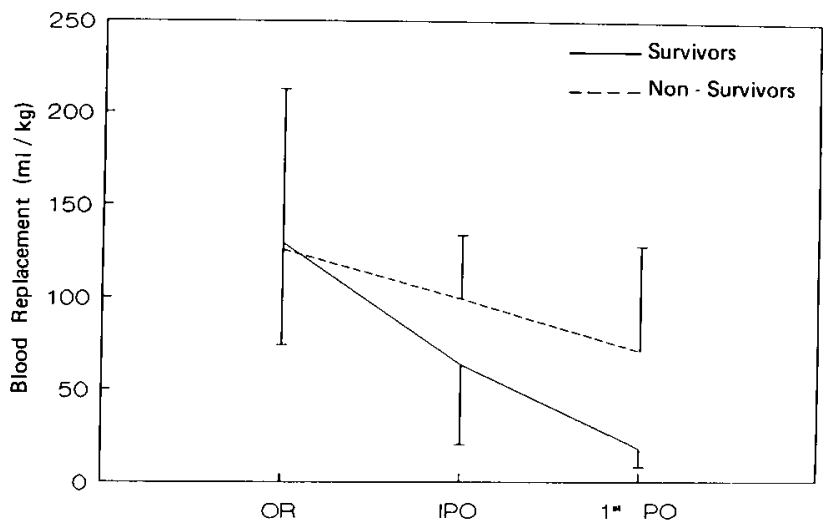

Figure 3 - Blood replacement as a function of time. Volume replacement was greater in non-survivors than in survivors. There was no statistical difference between groups. OR: operating room, IPO: immediate, 1 st: first postoperative day. phosphate in red cells, and its concentration is equimolar to the hemoglobin. Together with the ATP, 2,3 DPG links itself to the hemoglobin and competes with $\mathrm{O}_{2}$, decreasing oxygen hemoglobin affinity, ie shifting $\mathrm{OH}-\mathrm{DC}$ rightwards.

The basic mechanism for changing 2,3 DPG concentration seems to be related to the hydrogen ion concentration in red cells. These concentrations increase or decrease together.

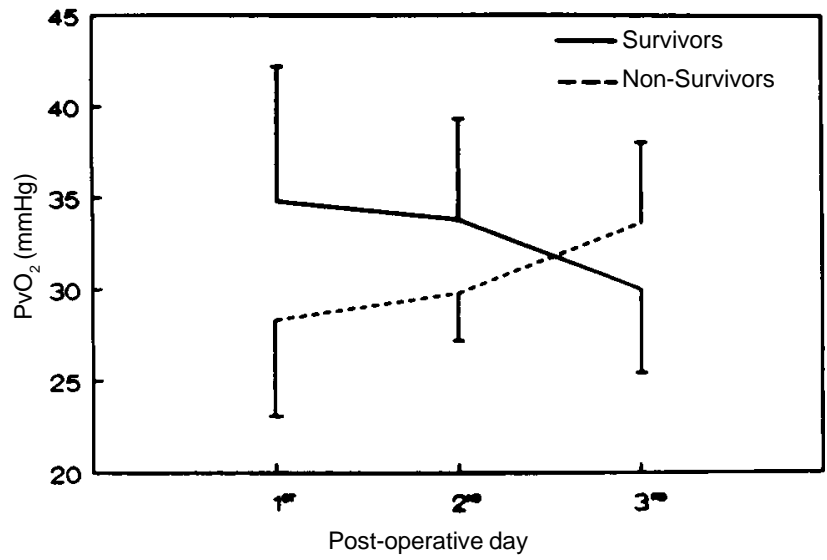

Figure $4-\mathrm{P}_{\mathrm{v}} \mathrm{O}_{2}$ determination as a function of time, there was no statistal difference between groups. Non survival patients showed lower values in the first postoperative day. $1^{\text {st }}, 2^{\text {nd }}$ and $3^{\text {rd }}$ postoperative days. 
Table 2

Hemodynamic Data

\begin{tabular}{|c|c|c|c|c|c|}
\hline VARIABLE & & $1^{\text {st }}$ P.O. & $2^{\text {nd }}$ P.O. & $3^{\text {rd }}$ P.O. & $p$ value \\
\hline $\mathrm{Cl} \mathrm{L} / \mathrm{min} / \mathrm{m}^{2}$ & $\begin{array}{l}\mathrm{S} \\
\mathrm{N}\end{array}$ & $\begin{array}{l}4.12 \pm 1.00 \\
3.72 \pm 1.34\end{array}$ & $\begin{array}{l}4.81 \pm 0.64 \\
3.72 \pm 1.10\end{array}$ & $\begin{array}{l}4.43 \pm 0.75 \\
3.57 \pm 0.72\end{array}$ & NS \\
\hline RAP $\mathrm{mmHg}$ & $\begin{array}{l}\mathrm{S} \\
\mathrm{N}\end{array}$ & $\begin{array}{l}12.33 \pm 8.48 \\
14.33 \pm 6.02 \\
\end{array}$ & $\begin{array}{l}12.50 \pm 1.64 \\
14.50 \pm 3.73 \\
\end{array}$ & $\begin{array}{l}11.00 \pm 4.34 \\
13.67 \pm 5.35 \\
\end{array}$ & NS \\
\hline WP $\mathrm{mmHg}$ & $\begin{array}{l}\mathrm{S} \\
\mathrm{N}\end{array}$ & $\begin{array}{l}15.17 \pm 8.45 \\
15.17 \pm 3.31\end{array}$ & $\begin{array}{r}15.00 \pm 3.16 \\
19.83 \pm 5.88 \\
\end{array}$ & $\begin{array}{c}16.17 \pm 9.41 \\
14.83 \pm 3.76 \\
\end{array}$ & NS \\
\hline PVR dyne.sec/cm $/ \mathrm{m}^{2}$ & $\begin{array}{l}\mathrm{S} \\
\mathrm{N}\end{array}$ & $\begin{array}{l}126.00 \pm 31.76 \\
154.00 \pm 74.95\end{array}$ & $\begin{array}{l}125.83 \pm 64.38 \\
193.67 \pm 42.72\end{array}$ & $\begin{array}{l}139.83 \pm 62.92 \\
198.50 \pm 25.40\end{array}$ & NS \\
\hline SVR dyne.sec $/ \mathrm{cm}^{5} \cdot \mathrm{m}^{2}$ & $\begin{array}{l}\mathrm{S} \\
\mathrm{N}\end{array}$ & $\begin{array}{c}805.08 \pm 99.99 \\
625.17 \pm 206.06\end{array}$ & $\begin{array}{l}659.83 \pm 129.04 \\
794.67 \pm 441.65\end{array}$ & $\begin{array}{l}755.83 \pm 30.78 \\
692.83 \pm 64.58\end{array}$ & NS \\
\hline $\begin{array}{l}\mathrm{HR} \\
\text { bpm }\end{array}$ & $\begin{array}{l}\mathrm{S} \\
\mathrm{N}\end{array}$ & $\begin{array}{c}87.33 \pm 17.60 \\
113.83 \pm 20.21\end{array}$ & $\begin{array}{c}93.17 \pm 11.11 \\
111.67 \pm 10.13\end{array}$ & $\begin{array}{c}96.00 \pm 25.32 \\
108.83 \pm 21.12\end{array}$ & NS \\
\hline MAP $\mathrm{mmHg}$ & $\begin{array}{l}\mathrm{S} \\
\mathrm{N}\end{array}$ & $\begin{array}{l}81.67 \pm 13.29 \\
59.50 \pm 10.67\end{array}$ & $\begin{array}{l}75.00 \pm 15.17 \\
71.83 \pm 10.23 \\
\end{array}$ & $\begin{array}{r}75.00 \pm 10.00 \\
70.50 \pm 14.53 \\
\end{array}$ & NS \\
\hline PAP mmHg & $\begin{array}{l}\mathrm{S} \\
\mathrm{N}\end{array}$ & $\begin{array}{l}26.17 \pm 10.50 \\
26.50 \pm 6.22\end{array}$ & $\begin{array}{c}26.83 \pm 4.31 \\
33.33 \pm 10.25\end{array}$ & $\begin{array}{c}27.67 \pm 11.08 \\
28.17 \pm 7.47\end{array}$ & NS \\
\hline
\end{tabular}

CI: cardiac index; RAP: right atrium pressure; WP: wedge pressure; PVR: pulmonary arterial resistence; SVR: systemic vascular resistence; HR: heart rate; MAP: medium arterial pressure; PAP: pulmonary arterial pressure; S: survivors; N: non-survivors; NS: statistically not significant (level $p<0.05)$.

Ideally, hemorrhagic volume lost should be replaced with fresh blood, which could maintain adequate levels of 2,3 DPG. In this study, it was observed that $\mathrm{O}_{2}$ consumption increased with persistent $\mathrm{O}_{2} \mathrm{ER}$ increases.

Unfortunately, despite massive volume administration and blood transfusion and drug support, we were unable to maintain oxygen availability at reasonable levels to meet tissue demands. The inadequacy of $\mathrm{O}_{2}$ supply can be shown by the elevated lactate levels. In fact, although there was a significant increase in lactate levels during the study, the high values obtained reflected a disorder in the oxygen supply. The inadequacy of $\mathrm{O}_{2}$ transport was corroborated by the elevated mortality observed (50\%), mainly in patients whose serum lactate remained higher than $20 \mathrm{mg} \cdot \mathrm{dl}^{-1}$. Conversely, other factors, such as the degree of $\mathrm{O}_{2}$ dissociation from hemoglobin, can explain an abnormal $\mathrm{O}_{2}$ supply to the cells ${ }^{(9,10,11,12,13)}$. Several studies have speculated that changes in $\mathrm{pH}$, temperature, $\mathrm{PaCO}_{2}$ and phosphate concentration are the most common factors associated with altered hemoglobin-oxygen affinity ${ }^{(5)}$.

In critical patients, multiple factors can change the optimum relation between oxygen supply/demand. Because of this, it is hard to specify a single factor responsible for increasing the level of blood lactate. We observed a leftward shifted $\mathrm{P}_{50}$, as shown in figure 3. Mild alkalosis and a slight decrease in levels of organic phosphate in red blood cells could explain the OH-DC deviation. It has been previously shown that 2,3 DPG levels rapidly decrease in whole blood and packed red cells stored in CPD, CPDA-1 or CPDA-2 as anticoagulants ${ }^{(14,15,16,17)}$. In our study there was no important decrease in 2,3 DPG levels, even in patients whose lactate levels were very high. We also did not find any statistical difference in 2,3 DPG levels between surviving and non-surviving patients. We observed an extreme leftward shift of the OH-DC in the non-survivors group on the first postoperative day. The main objective of this study was, independent of any clinical preoperative condition, to verify the influence on oxygen transportation of 2,3 DPG deprivation caused by massive transfusion. The 2,3 DPG levels obtained cannot explain our results.

Simultaneously, there was a sharp elevation in lactate levels in the same group during the same period. The lack of consensus about the relationship between critical values of $\mathrm{OH}-\mathrm{DC}$ and oxygen delivery in clinical situations cannot provide a reasonable explanation for this finding. Despite the theoretical importance of $\mathrm{P}_{50}$ in $\mathrm{O}_{2}$ delivery to the tissues, there are some contradictory aspects. $\mathrm{P}_{50}$ is not decisive in decreasing $\mathrm{O}_{2}$ release to tissues during normoxia, except at very low $\mathrm{O}_{2}$ loading ${ }^{(18)}$.

In our study, the $\mathrm{O}_{2} E R$ remained elevated at all times and there was no difference in $\mathrm{O}_{2}$ ER between surviving and non-surviving patients. This fact can be explained by unsatisfactory $\mathrm{O}_{2}$ uptake. Decreased lactate levels in the surviving group may suggest that most, if not all, tissues either tolerate acutely reduced $\mathrm{O}_{2}$ loading or utilize 
microcirculatory regulation to optimize $\mathrm{VO}_{2}$ towards normal.

In conclusion, patients submitted to massive transfusions following cardiovascular surgery present cell oxygenation disturbances probably as a result of $\mathrm{O}_{2}$ transport inadequacy. Many factors may be involved in oxygen supply/demand imbalances.

\section{ACKNOWLEDGMENTS}

The authors thank Julia Tizue Fukushima and Rita Helena Antonelli Cardoso for statistical analysis and Regina Celia Martins de Oliveira and Celia Cassaro Strunz who did the laboratory determinations.

\section{Resumo}

Objetivo: Avaliar a oxigenação sangüínea, a hemodinâmica e a bioquímica (2,3-Difosfoglicerato, Lactato e Gases Sangüíneos) no pós-operatório de pacientes submetidos a cirurgia cardíaca que foram politransfundidos. Desenho: estudo prospectivo. Local: Instituto do Coração do Hospital das Clínicas da Faculdade de Medicina da Universidade de São Paulo. Partipantes: Doze pacientes de pós-operatório de cirurgia cardíaca que foram politransfundidos, dentre os quais seis evoluíram para o óbito durante os três primeiros dias de pós-operatório. Mensuração e resultados: 0 grupo de não sobreviventes ( $\mathrm{n}=6$ ) apresentou níveis elevados de lactato sangüíneo e $P_{50}$ significativamente menor $(p<0,05)$ que o grupo de sobreviventes. Ambos os grupos, apresentaram aumento de consumo e extração de oxigênio, além de discreta diminuição dos níveis de 2,3Difosfoglicerato, embora sem diferença significativa entre os grupos. Conclusão: este estudo mostra que pacientes politransfundidos no pós-operatório de cirurgia cardíaca apresentam alterações na oxigenação celular, provavelmente decorrentes de inadequado transporte de oxigênio.

\section{REFERENCE}

1. Schumacker PT, Cain SM. The concept of a critical oxygen delivery. Intensive Care Med 1987;13:223-229.

2. Shappell SD, Lenfant CJM. Adaptive, genetic, and iatrogenic alterations of the oxyhemoglobin-dissociation curve. Anesthesiology 1972;13:127-139.

3. Oski FA, Gottlieb AJ, Miller WW, Delivoria- Papadopoulos M. The effects of deoxygenation of adult and fetal hemoglobin on the synthesis of red cell 2,3-diphosphoglycerate and its in vivo consequences. J Clin Invest 1970;49:400-407.

4. Valeri CR, Collins FB. Physiologic effects of 2,3-DPG-depleted red cells with high affinity for oxygen. J Appl Physiol 1971;31:823-827.

5. Sheldon GF. Diphosphoglycerate in massive transfusion and erythropoiesis. Crit Care Med 1979;7:407-409.

6. Canizaro PC, Nelson JL, Hennessy JL, Bright PB. A technique for estimating the position of the oxygenhemoglobin dissociation curve. Ann Surg 1974;180:364367

7. Aberman A, Cavanilles J, Trotter E, Jacobson E, Shubin H, Weil MH. Effect of measurement error on calculated P50. Clin Res 1973;21:221-226.

8. Shibutani K, Komatsu T, Kubal K, Sanchala V, Kumar V, Bizzarri DV. Critical level of oxygen delivery in anesthetized man. Crit Care Med 1983;11:640-643.

9. Woodson RD, Auerbach S. Effect of increased oxygen affinity and anemia on cardiac output and its distribution. J Appl Physiol 1982;53:1299-1306.
10. Gutierrez G, Andry JM. Increased hemoglobin $\mathrm{O}_{2}$ affinity does not improve $\mathrm{O}_{2}$ consumption in hypoxemia. J Appl Physiol 1989;66:837-843.

11. Gutierrez G, Pohil RJ, Strong R. Effect of flow on $\mathrm{O}_{2}$ consumption during progressive hypoxemia. J Appl Physiol 1988;65:601-607.

12. Warley AR, Gutierrez G. Chronic administration of sodium cyanate decreases $\mathrm{O}_{2}$ extraction ratio in dogs. J Appl Physiol 1988;64:1584-1590.

13. Cain SM. Oxygen delivery and uptake in dogs during anemic and hypoxic hypoxia. J Appl Phisiol 1977;42:228-234.

14. Vora S, West C, Beutler E. The effect of additives on red cell 2,3 diphosphoglycerate levels in CPDA preservatives. Transfusion 1989;29:226-229.

15. Pietersz RNI, Korte D, Reesink HW, Dekker WJA, Ende van den A, Loos JA. Storage of whole blood for up to 24 hours at ambient temperature prior to component preparation. Vox Sang 1989;56:145-150.

16. Moore GL, Ledford ME, Merydith A. The biochemical effects on CPDA-2-drawn red blood cells of delayed refrigeration prior to component preparation. Transfusion 1982;22:485-487.

17. Moroff G, Morse EE, Katz AJ, Kahn RA, Dende D, Swatman L, Staggs SD. Survival and biochemical characteristics of stored red cells preserved with citrate-phosphatedextrose-adenine one and two and prepared from whole blood maintained at $20^{\circ}$ to $24^{\circ} \mathrm{C}$ for eight hours following phlebotomy. Transfusion 1984;24:115-119.

18. Schumacker PT, Long GR, Wood LDH. Tissue oxygen extraction during hypovolemia: role of hemoglobin P50. J Appl Physiol 1987;62:1801-1807. 